\title{
Potential for nutrient and faecal bacteria losses from a dairy pasture under border-dyke irrigation: a case study
}

\author{
P.L. CAREY ${ }^{1}$, J.J. DREWRY2 ${ }^{2}$ R.W. MUIRHEAD ${ }^{2}$ and R.M. MONAGHAN ${ }^{2}$ \\ ${ }^{1}$ Land Research Services Ltd, c/o Soil and Physical Sciences Group, P.O. Box 84, Lincoln University \\ ${ }^{2}$ AgResearch, Invermay Agricultural Centre, PB 50034, Mosgiel
}

careyp2@yahoo.co.nz

\begin{abstract}
The potential for water, nutrient and faecal bacteria transport in border-dyke run-off from dairy pasture was monitored within the South Canterbury catchment of Waikakahi during the 2002/2003 milking season. The Waikakahi stream runs lengthways through the catchment and characteristically has mean summer flows approximately four-times that for winter $(2002 ; 1850 \mathrm{l} / \mathrm{s}$ vs 450 $1 / \mathrm{s}$, respectively). This extra flow is assumed to be fed largely from irrigation run-off and drainage. Three borders of a flood-irrigated dairy paddock in the upper part of the catchment, located on Temuka gley soils, were directed off to a collection weir over which seven irrigation events were recorded for runoff volume, Escherichia coli $(E$. coli) and phosphorus $(\mathrm{P})$ and nitrogen $(\mathrm{N})$ concentrations. Irrigation volume loss from the Waikakahi field site was, on average, $50 \%$ of total inflow and considerably higher than the accepted recommended maximum in Australia of $10 \%$. However, it was accepted that this represented a possible "worst-case" scenario. Run-off totalled $2600 \mathrm{~m}^{3} / \mathrm{ha}$ over the first six events with the large volume at least partly attributed to insufficient infiltration into the soil due to the low hydraulic conductivity of the Temuka soils. Irrigation volumes entering the catchment were generally sufficient to supply $90-100 \mathrm{~mm}$ depth of water across the area but border gradients appear too steep to allow sufficient infiltration before the water ran to the end of the border. Re-grading borders to allow for the slower infiltration rates of heavy texture soils is suggested.
\end{abstract}

Concentrations of $\mathrm{P}, \mathrm{N}$ and $E$. coli in irrigation run-off were consistently higher than the acceptable critical limits for water quality and even with in-stream dilution, would continue to exceed water standards. Total-P and dissolved reactive phosphorus (DRP) concentrations in nonfertiliser affected run-off (first six events) were high at $\sim 0.8 \mathrm{mg}$ and $0.6 \mathrm{mg} \mathrm{P} / 1$, respectively. Total phosphorus and nitrogen losses over the seven events totalled 3.4 and $2.0 \mathrm{~kg} / \mathrm{ha}$, respectively. The source of most $P$ appears to be from high soil P levels (soil Olsen P levels $>45 \mu \mathrm{g}$ / $\mathrm{ml}$ ), indicating the importance of ensuring soil Olsen $\mathrm{P}$ values remain within the agronomic target range (20-30 $\mu \mathrm{g} / \mathrm{ml}$ ). The presence of fertiliser and timing of application, and days between irrigation and last grazing, were also important determinants of nutrient concentrations in irrigation run-off.

Flow obstructions within the headrace channel were linked to differences in volumes entering individual borders and also caused unintended inflow from irrigation of the adjacent set of borders. Improving the smoothness of the headrace channel is required to achieve more even watering. A number of other contributing factors that may lead to excessive irrigation run-off were also noted. In this particular set in the first instance, inflow times needed shortening to reduce water loss. Reducing the volume of irrigation run-off overall entering the stream remains the chief means of reducing nutrient and faecal bacteria contaminant loadings and improving water quality.

Keywords: border-dyke irrigation, dairy pasture, faecal bacteria, nitrogen, phosphorus

\section{Introduction}

Surface run-off or overland flow from agricultural land is a known significant contributor to declining water quality by way of faecal bacteria, phosphorus (P) and nitrogen (N) inputs (Doran \& Linn 1979; McDowell et al. 2001). In Canterbury, large areas (>80,000 ha) of intensively farmed grassland are flood-irrigated using border-dyke systems with 20000 ha irrigated from the Waitaki River in the Morven-Glenavy-Ikawai scheme. This figure is set to increase further. There is concern for the potential of this practice to cause significant impairment of stream and river water quality due to the pollutants entrained in the run-off. In Australia there has been considerable study into flood-irrigated systems under dairy farming, their ability to carry contaminants into waterways, and how this might be minimised (Mundy et al. 2003; Nexhip \& Austin 1998; Nexhip et al. 1997). Key findings in this research were the significant relationships between increased $\mathrm{P}$ and $\mathrm{N}$ concentrations in runoff with increased stocking pressure (as a function of excreta input), pasture defoliation, and irrigation after fertiliser application. However, limiting irrigation runoff loss is the primary means of reducing nutrient losses. Recommended best practice has suggested zero runoff for the first two irrigations after fertilising and limiting runoff from remaining irrigations to $10 \%$ or less of inflow volume (Nexhip et al. 1997).

In this context, a flood irrigation study was undertaken 
as part of the Dairy InSight Best Practice Dairy Catchments Project. Our objective in the Waikakahi catchment situated in the lower Waitaki Valley in South Canterbury, was to quantify nutrient and volume losses in flood-irrigation run-off from a border-dyke paddock under dairy farming. The Waikakahi catchment has received recent media attention due to declining water quality of the Waikakahi stream and the perceived effect this has on trout numbers and other aquatic life. This deterioration has coincided with increasing intensification of dairy farming in the catchment. The water quality indicators of most concern have been sediment loading, the resulting reduced clarity, high summer faecal indicator bacteria counts, and $\mathrm{P}$ and $\mathrm{N}$ loadings (Meredith et al. 2003). With the majority of the catchment now fenced from stock $(>90 \%)$, water clarity and sediment loading has improved considerably but nutrient and bacterial levels in the stream remain of concern. Approximately $95 \%$ of the 4100 ha (effective) of flat farmland contained within the catchment is irrigated through the MorvenGlenavy-Ikawai Irrigation Scheme, with about $80 \%$ of this flood-irrigated using border-dyke.

This study chose a site where irrigation run-off was observed to be substantial and regularly entering drainage channels and thus, represented a possible "worst-case" scenario. Our objectives were twofold; to record the faecal bacteria, $\mathrm{P}$ and $\mathrm{N}$ levels in irrigation run-off for a number of flood-irrigation events (and consequently, what effect this irrigation drainage might have on stream quality) and secondly, to establish what were the chief contributing factors that led to any excessive irrigation run-off.

\section{Materials and methods}

\section{Site selection}

One dairy farm (situated in the upper half of the catchment) was chosen as the trial site. The soil at this site was a Temuka silt loam (Typic Orthic Gley soil) which together with the associated Wakanui soil series, comprises about $22 \%$ of the catchment area. Three adjacent borders, $20 \mathrm{~m}$ wide, were modified within one paddock to restrict flow across a $0.5 \mathrm{~m}$ wide weir in each border (Figure 1). All three borders were approximately 130 metres long and were irrigated simultaneously from a $2 \mathrm{~m}$ wide weir at the headrace of each border. The paddock was fertilised twice, once in September with $200 \mathrm{~kg} / \mathrm{ha} 20 \%$ potassic (K) di-ammonium phosphate 15 sulphur (kg/ha; $20 \mathrm{~N}, 25 \mathrm{P}, 20 \mathrm{~K}, 15 \mathrm{~S})$ and secondly in April, after the main irrigation season with $400 \mathrm{~kg} / \mathrm{ha}$ $30 \%$ potassic superphosphate and $80 \mathrm{~kg} \mathrm{~N} / \mathrm{ha}$ as urea.

\section{Field measurement protocol}

Our intention was to record as many of the 13-14 irrigations scheduled as practicable over the course of
Figure 1 Diagram of the monitoring set-up for the three irrigation borders.

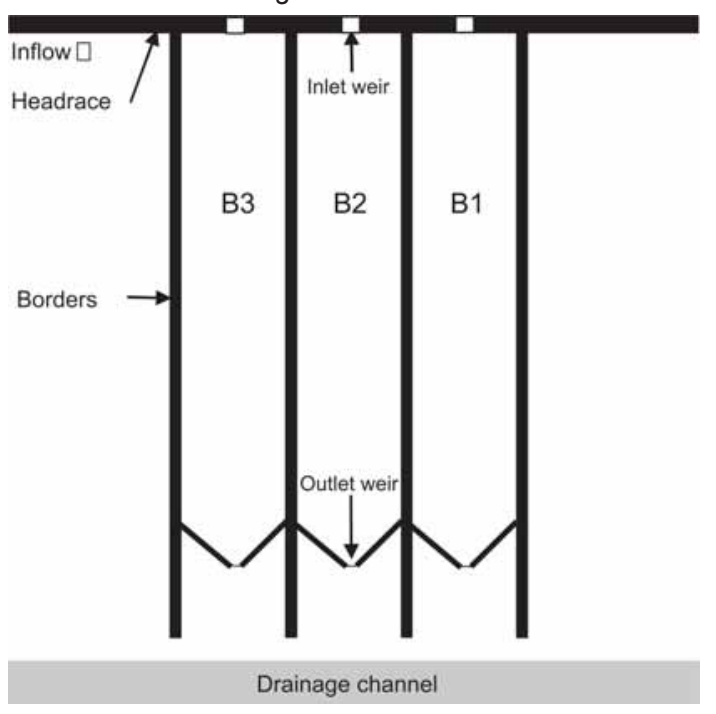

the normal irrigation season (September to April). This resulted in seven events being attended, most nominally of 90 minutes duration, with on average 250 cubic metres of water entering each border to provide a potential infiltration depth of $90-100 \mathrm{~mm}$. Actual inflow volumes were calculated from recording weir heights for each event. A hydrograph for each border was recorded by measuring outlet $(0.5 \mathrm{~m})$ flow stage height concurrently with collection of 12-15 water samples over the stage height range. An in-flow water sample was also collected for analysis. Numbers of cowpats, residual pasture dry matter (DM) and soil moisture content (SMC) were recorded prior to irrigation within each border.

At the completion of the normal irrigation schedule an additional event $\left(7^{\text {th }}\right)$ was staged to observe the effects of halving irrigation time from 90 to $45 \mathrm{mins}$, and to examine the effect of irrigation on recently applied $\mathrm{P}$ and $\mathrm{N}$ fertiliser (superphosphate and urea applied ten days previously). No attempt was made to modify farmer irrigation practice until this last event.

\section{Analyses}

A range of bacteriological and chemical analyses were conducted on selected samples (six for each border) taken from each hydrograph and are shown in Table 1. Total run-off volume and nutrient mass contained was calculated using flow-weighted arithmetic means whilst geometric means were calculated for Escherichia coli (E. coli) using most probable numbers (MPN). The faecal coliform group of bacteria is made up of a number of different species of bacteria with the dominant species (ie. $>80 \%$ ) generally E.coli (Ministry for the Environment 2003). Consequently, substrate tests for $E$. coli are used 
Table 1 Bacterial or chemical analysis and methodology or application note used.

\begin{tabular}{ll}
\hline \multicolumn{1}{c}{ Analysis } & \multicolumn{1}{c}{ Method } \\
\hline E. coli MPN (most probable numbers) & $\begin{array}{l}\text { (APHA enzyme substrate test 9223B), (Edberg et al. 1988; } \\
\text { Niemela et al. 2003) }\end{array}$ \\
Dissolved reactive phosphate (DRP) & $\begin{array}{l}\text { Total dissolved phosphate (TDP) According to Blakemore et al. } \\
\text { (1987) and Tecator application note ASN 60-04183 }\end{array}$ \\
Total-P & $\begin{array}{l}\text { Peroxodisulphate oxidation (Ebina et al. 1983) and FIA analysis } \\
\text { (phosphoromolybdate method). }\end{array}$ \\
Ammonium & FIA analysis Tecator application note 50-02/82 \\
Nitrate & FIA analysis Tecator application note 62-02/83 \\
Metal cations & Waters ion exchange chromatograph using an \\
Total suspended solids & Alltech universal cation column \\
Volatile suspended solids & Nebraska WEA Lab manual - \\
\hline
\end{tabular}

as the main means of assessing the relative input of faecal matter in a water body. Statistical analysis was conducted by calculating means and standard errors for variation between borders (or standard deviations for geometric means) using MS Excel data analysis and multipleregression analysis using GENSTAT $^{\circledR}$.

\section{Results}

\section{Run-off volumes}

Run-off volumes from the seven events attended (dates shown in Table 4) were particularly large and exited the paddock through open drains and culverts, with water losses for individual borders ranging from $120-600 \mathrm{~m}^{3} /$ ha ( 12-60 mm water depth lost) (Figure 2). The average proportion of in-flow volume lost as runoff was approximately 50\% (range 40-60\%) and totalled 2600 $\mathrm{m}^{3} /$ ha over the first six events. This loss could be expected to be $50 \%$ higher after adding in run-off losses from irrigation events missed during the course of the season. Event 7 (45 mins duration), which was additional to normal irrigation scheduling, had the lowest overflow volume of all the events. However, this still led to a flow loss of $\sim 40 \%$, although SMC beforehand was relatively high at $34 \% \mathrm{v} / \mathrm{v}$.

Table 2 Mean soil moisture content (SMC), cowpat deposition and residual DM for each irrigation event.

\begin{tabular}{lccc}
\hline Event & $\begin{array}{c}\text { SMC } \\
(\% \text { v/v })\end{array}$ & $\begin{array}{c}\text { Cowpats/ } \\
\text { border }\end{array}$ & $\begin{array}{c}\text { Residual DM } \\
(\mathrm{kg} / \mathrm{ha})\end{array}$ \\
\hline 1 & 19.8 & 315 & 2099 \\
2 & 29.4 & 243 & 2373 \\
3 & 27.9 & 284 & 2056 \\
4 & 19.9 & 241 & 3097 \\
5 & 22.1 & 205 & 2982 \\
6 & 27.0 & 179 & 3416 \\
7 & 34.1 & 205 & 3554 \\
\hline Mean & 25.7 & 244 & 2670 \\
\hline
\end{tabular}

A number of potential factors such as headrace condition, residual DM and SMC were observed or measured for their ability to influence run-off. Of these, only race condition could be singled out as significant, with flow heights over the weirs considerably greater for the border nearest the inlet gate of the headrace (B3, Figure 1) compared with borders further away. The unequal inlet volumes created between borders (inset, Figure 2) subsequently led to run-off volumes that also differed accordingly. Mean run-off per event for B3 was significantly higher at $162 \mathrm{~m}^{3}$ than for the border furthest away (B1) at $109 \mathrm{~m}^{3}$. Unintended inflow into the monitored borders was also an issue and significant for a number of events whenever irrigation of the adjacent downstream set occurred prior to the monitored set. The border nearest the headrace inlet gate (B3) was again the most affected, with as much as $30 \%$ more inflow than intended.

\section{Faecal bacteria}

Bacterial contamination of run-off was very high at times and consequently, critical limits for $E$. coli contamination [occasional recreational limit 550 coliform units-cfu/ 100 ml; (Department of Health 1992 ; Ministry for the Environment 2003)] were grossly exceeded (range 1001000 times). With E. coli MPN values appearing considerably higher both in summer, and with irrigation occurring shortly after grazing (Figure 3 ), it was decided to run a multiple regression analysis against a number of variables including days-since-grazing and temperature. The regression relationship was described by the following equation:

$\log _{10}($ E.coli $)=3.15-0.03 \times$ Days $^{*}+0.09 \times$ MaxTemp ** $R^{2}=0.84$

where: Days is the intervening period between last grazing and irrigation, MaxTemp is the average maximum temperature between grazing and irrigation, and where $* / * *$ denotes the probability significance of each variable 
Figure 2 Mean runoff volume per ha and percentage of in-flow volume lost as run-off for each irrigation event (in chronological order). Standard error bars are shown for variation between borders. Inset graph shows mean inlet flow volumes for borders B1-B3 during events 1-6.

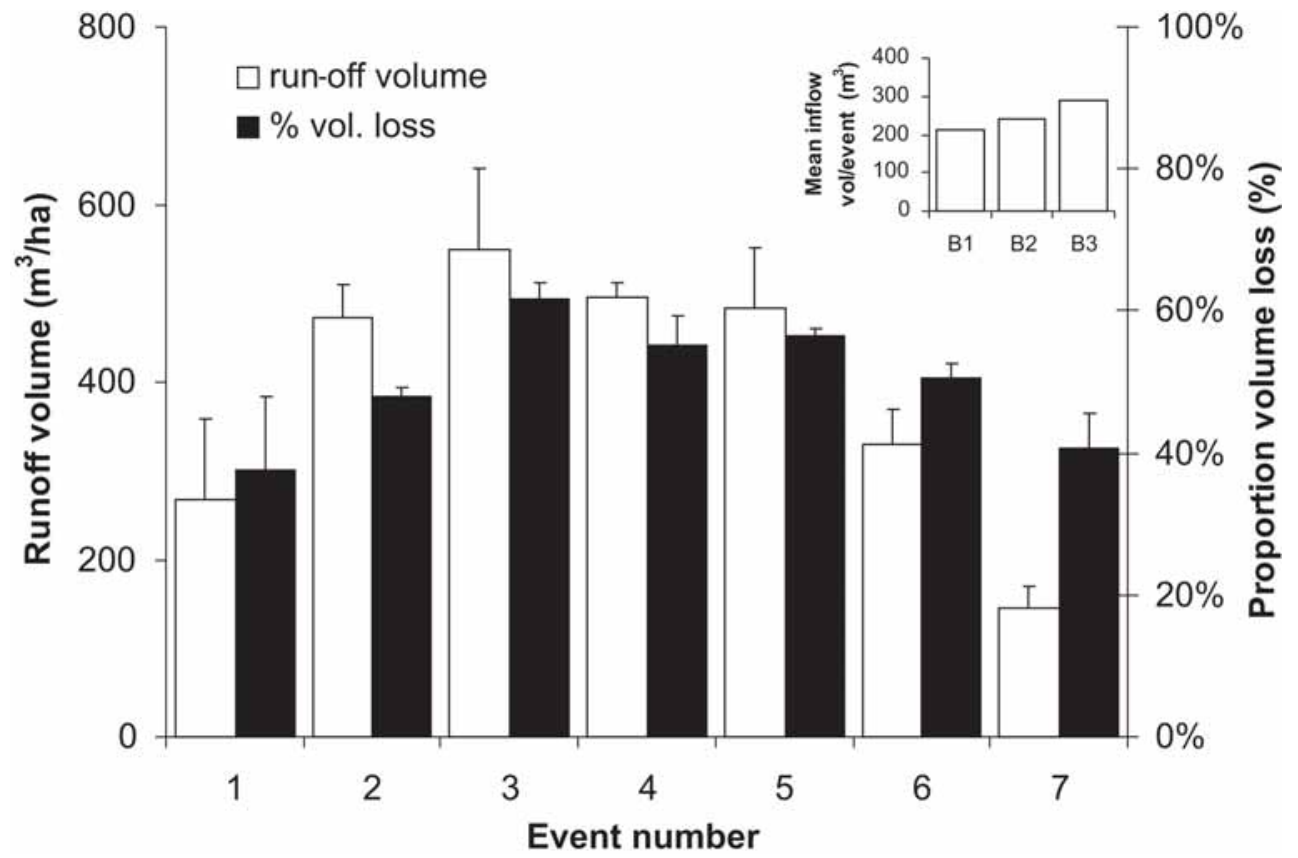

Figure 3 E. coli MPN (geometric flow-weighted means) of outflow vs time since grazed (critical limit for recreational water use shown as dotted line). Standard deviations shown by bars.

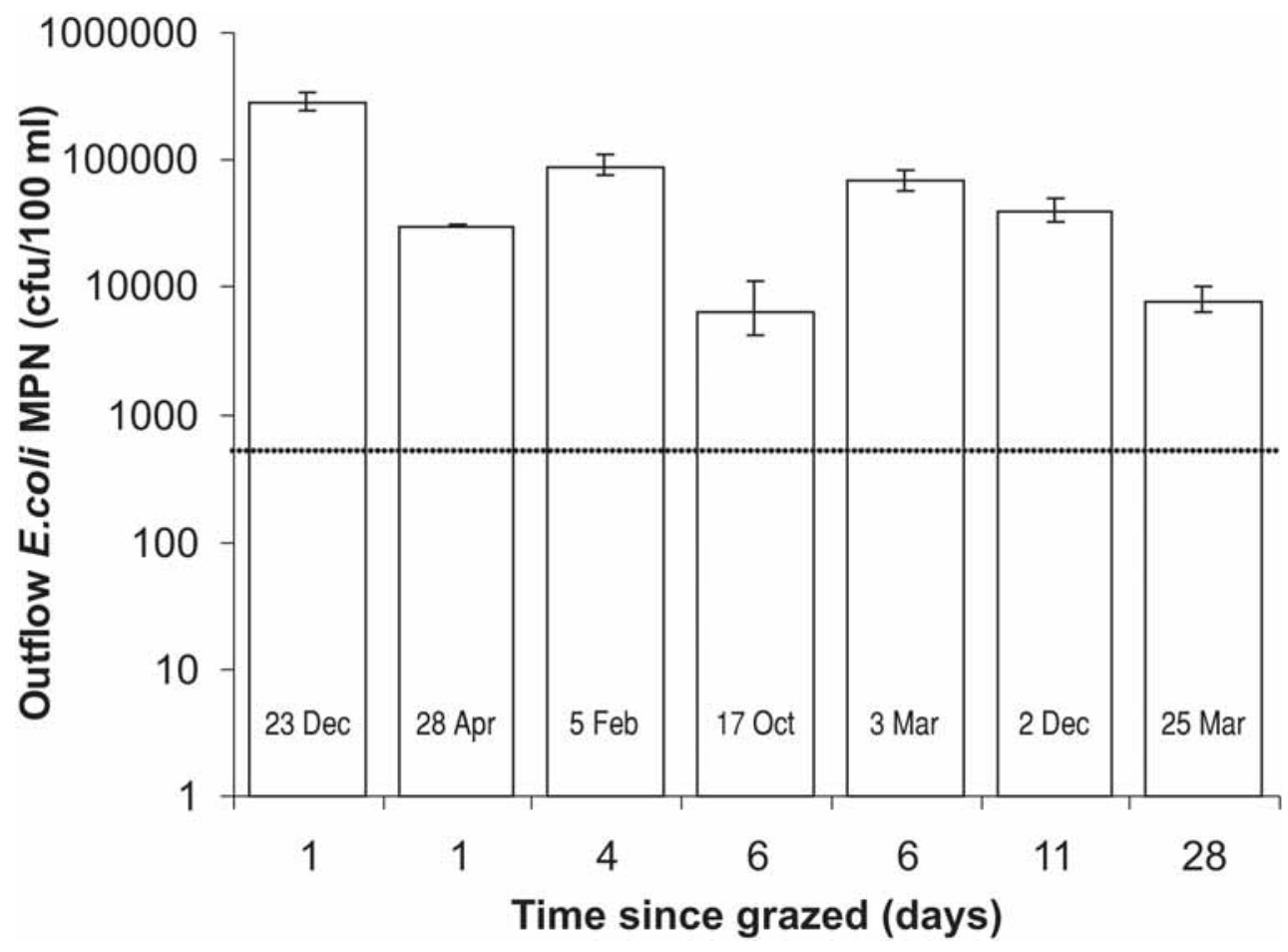


Table 3 Estimates of DRP, inorganic-N and E. coli loadings (most probable numbers-MPN) in the Waikakahi Stream compared with estimates of losses from flood irrigation run-off on Temuka and Wakanui soils.

Catchment discharge rates

Mean stream summer flow rate (bottom end catchment)

Mean stream summer DRP values (Meredith et al. 2003)

$1850 \mathrm{l} / \mathrm{s}$

Mean stream summer Inorg-N values (Meredith et al. 2003)

$0.08 \mathrm{mg} P / \mathrm{I}$

Mean stream summer E. coli MPN (Meredith et al. 2003)

Mean daily DRP loading measured in the stream

Mean daily inorganic-N loading measured in the stream

Mean daily $E$. coli loading measured in the stream

$1.7 \mathrm{mg} \mathrm{N} / \mathrm{I}$

1500 MPN /100 ml

$19 \mathrm{~kg} P$

$255 \mathrm{~kg} \mathrm{~N}$

$2.4 \times 10^{12} \mathrm{cfu}$

Flood irrigation run-off losses

Estimate of border-dyked area of Temuka/Wakanui soils)

800 ha

Area of Temuka/Wakanui soils irrigated per day (5\%)

40 ha

a Mean run-off flow rate

$560 \mathrm{l} / \mathrm{s}$

Mean summer run-off DRP value ${ }^{b}$

$0.6 \mathrm{mg} P / /$

Mean summer inorganic- $N$ value ${ }^{b}$

$0.3 \mathrm{mg} \mathrm{N} / \mathrm{I}$

c Mean summer MPN of E. coli in the run-off

Mean daily DRP loading estimated from run-off

Mean daily inorganic-N loading estimated from run-off

$3.9 \times 10^{4} \mathrm{cfu} / 100 \mathrm{ml}$

Mean daily $E$. coli loading estimated from run-off

$4.8 \mathrm{~kg} \mathrm{P}$

$2.8 \mathrm{~kg} \mathrm{~N}$

$3.4 \times 10^{12} \mathrm{cfu}$

a Based on assumed water loss of $25 \%$ of inlet flow.

b Excludes event 7.

c Geometric flow-weighted means used.

Figure 4 Concentrations (flow-weighted means) of DRP, total dissolved P (TDP) and Total-P in irrigation runoff vs. days since paddock was grazed. Critical limit for $P$ concentration in recreational water and standard error bars shown as solid line.

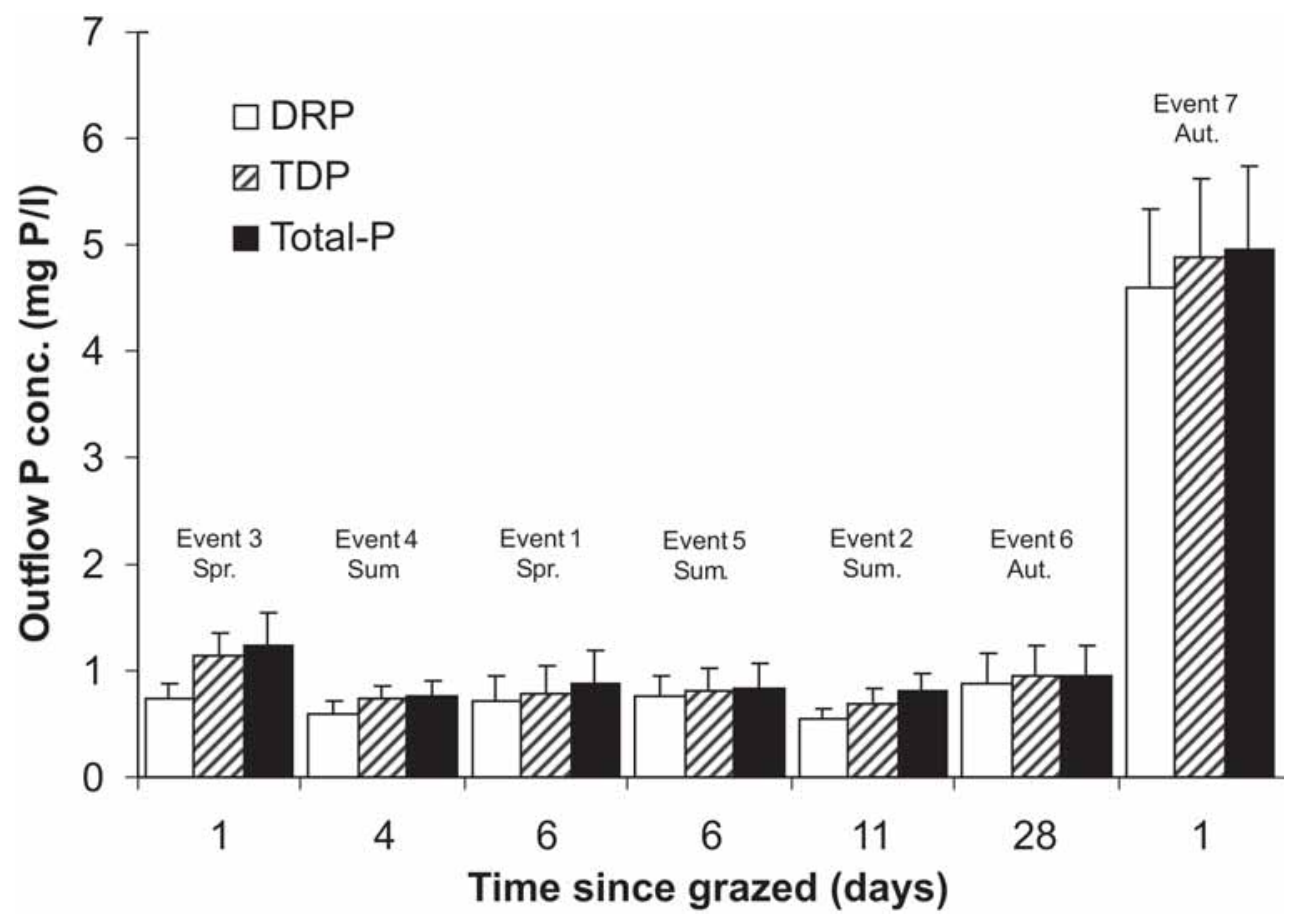


Table 4 Net aexport (kg/ha; -, gain) of total P, inorganic-N (IN), calcium (Ca), magnesium (Mg), potassium (K), sodium ( $\mathrm{Na}$ ) and total suspended solids (TSS) in irrigation run-off from the Waikakahi field sites.

\begin{tabular}{lccccccrr}
\hline Date & Event no. & Total-P & $\mathrm{IN}$ & $\mathrm{Ca}$ & $\mathrm{Mg}$ & $\mathrm{K}$ & $\mathrm{Na}$ & $\mathrm{TSS}$ \\
\cline { 2 - 8 } 17 Oct 02 & 1 & 0.7 & 0.3 & -5.7 & -0.2 & 0.5 & -1.6 & -44.8 \\
2 Dec 02 & 2 & 0.4 & 0.3 & -1.1 & 0.9 & 2.4 & 0.5 & -35.3 \\
23 Dec 02 & 3 & 0.2 & 0.4 & -1.1 & 0.5 & 4.7 & 0.8 & -9.2 \\
5 Feb 03 & 4 & 0.4 & 0.2 & -3.2 & 0.0 & 1.5 & -0.7 & -0.6 \\
3 Mar 03 & 5 & 0.5 & 0.2 & -5.2 & -0.1 & 1.0 & 0.0 & 2.6 \\
25 Mar 03 & 6 & 0.3 & 0.1 & -3.3 & 0.1 & 0.8 & -0.3 & -13.1 \\
28 Apr 03 & 7 & 0.8 & 0.5 & -1.2 & 0.1 & 2.5 & 0.1 & 32.2 \\
& A Net export & $\mathbf{3 . 4}$ & $\mathbf{2 . 0}$ & $\mathbf{- 2 0 . 7}$ & $\mathbf{1 . 4}$ & $\mathbf{1 3 . 3}$ & $\mathbf{- 1 . 1}$ & $\mathbf{- 6 8 . 2}$ \\
\hline
\end{tabular}

${ }^{a}$ Net export (-, gain) = total outputs (in run-off) - total inputs (in irrigation water).

Figure 5 Ammonium and nitrate concentrations (flow-weighted means) in irrigation run-off vs. days since last grazing. Event 7 shown on far right (1-day). Critical $\mathrm{N}$ limit for recreational water shown in solid line and standard error bars shown.

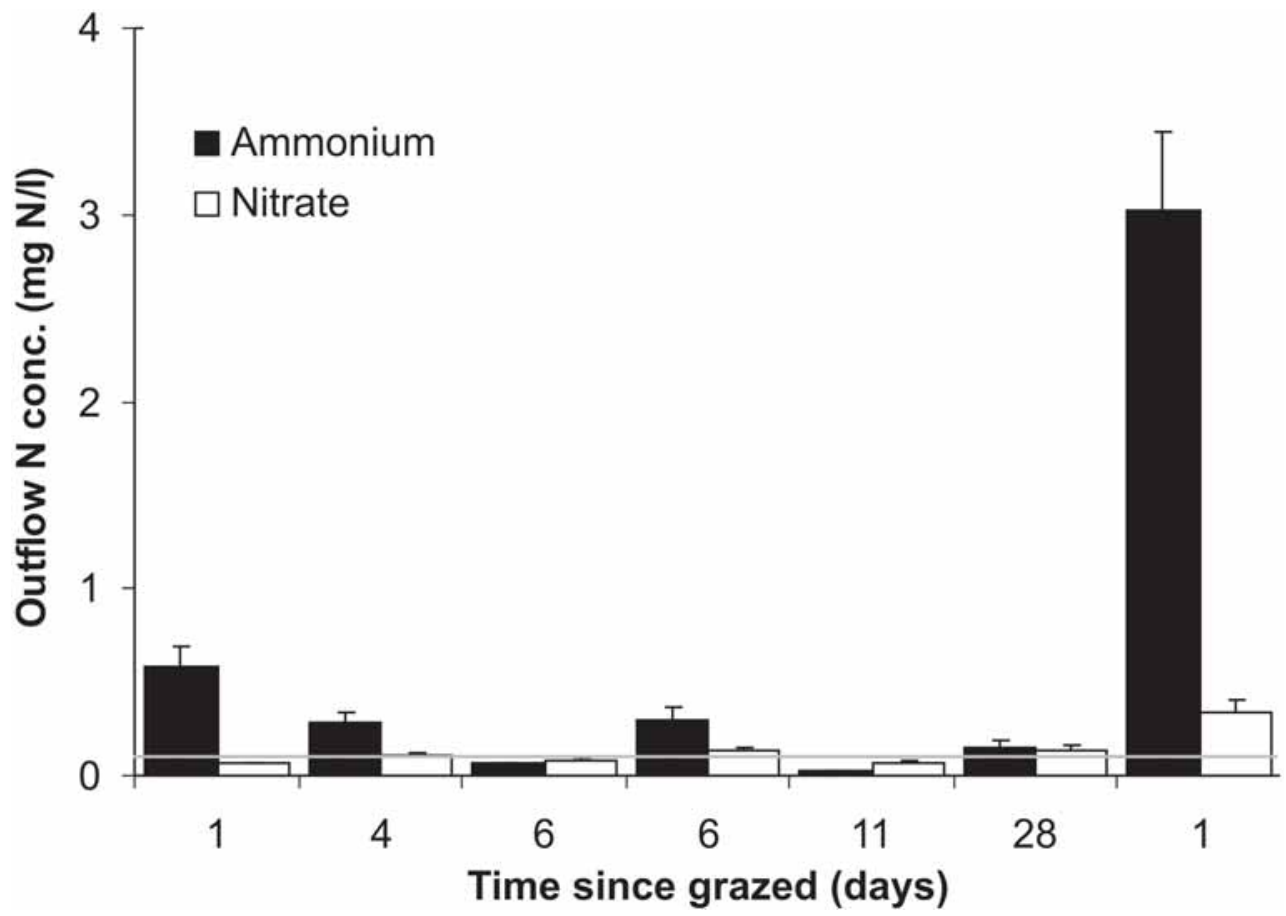

at $\mathrm{P}<0.05$ and $\mathrm{P}<0.01$ levels, respectively.

Although the number of cow pats deposited within the borders differed between events (Figure 2; mean range 179-315) no significant relationship was established between $E$. coli MPN values and deposition numbers, or indeed with SMC or residual DM.

\section{Phosphorus and other nutrient losses}

Total $\mathrm{P}$ concentrations in irrigation run-off ranged from 24-36 times that acceptable as the critical limit $(0.033$ $\mathrm{mg} \mathrm{P} / \mathrm{L}$ ) for stream water quality (Figure 4) meaning significant dilution would be required to lower it to this level. The sole exceptional circumstance to this was event 7 where $\mathrm{P}$ concentrations were extremely high ( $\sim 5 \mathrm{mg} \mathrm{P} / 1)$ due to the presence of soluble $\mathrm{P}$ fertiliser in the paddock. About $80 \%$ of the P present in events 1-6 was as DRP with mean concentrations (excluding event 7) around $0.6 \mathrm{mg} P / 1$. However, where irrigation occurred within one day of grazing (event 3), both dissolved unreactive $\mathrm{P}$ (Total dissolved $\mathrm{P}$ minus DRP) and organic-P, comprised a greater percentage of the $\mathrm{P}$ lost.

The estimated daily summer DRP loading from runoff (the fraction which most promotes weed growth) 
was about $25 \%$ that of the daily stream P loading (Table 3). Total $P$ exported in irrigation run-off totalled $3.4 \mathrm{~kg} /$ ha (net of $P$ in inflow) with losses ranging from $0.2-0.4$ $\mathrm{kg} \mathrm{P} / \mathrm{ha}$ for each event where grazing occurred between 4 and 28 days before irrigation (Table 4). However, for events 3 and 7 (both 1-day lag; event 7 P fertiliser present), $\mathrm{P}$ losses were considerably higher at about twice this figure (Table 4).

The estimated daily summer inorganic-N (ammonium + nitrate) loading from run-off was, in comparison, a much smaller proportion of the total stream loading of inorganic-N (Table 3). Total inorganic-N losses $(2.0 \mathrm{~kg} /$ ha) were lower than $\mathrm{P}$ losses but most of this $\mathrm{N}$ loss occurred in runoff as ammonium from a single event (event 7, Table 4) (Figure 4).

\section{Stream contaminant loadings vs. paddock losses}

Daily summer estimates of E. coli MPN's, DRP and inorganic-N losses from irrigation run-off for the 22\% of the catchment in Temuka and Wakanui soils are shown in Table 3 and compared with the equivalent stream concentrations of contaminants based on NIWA and ECAN monitoring (2002) data (Meredith et al. 2003). From this comparison it can be seen that a good proportion of the daily stream loadings of $E$. coli and DRP can be accounted for by run-off loss estimates from these soils. Only a small proportion $(<1 \%)$ however, of the stream $\mathrm{N}$ loading could be attributed to run-off $\mathrm{N}$ losses. We've assumed, for the purposes of this exercise, that $25 \%$ of irrigation inflow is lost as run-off, about half the figure found in this particular study.

\section{Discussion}

\section{Run-off losses}

The most significant feature of this field study was the large volume of run-off recorded for each irrigation event. Mean summer flows (2002) for the Waikakahi stream (Meredith et al. 2003) are approximately four-times that of winter flows ( $1850 \mathrm{l} / \mathrm{s}$ vs $450 \mathrm{l} / \mathrm{s}$, respectively) so the assumption is that irrigation run-off is the major contributor to this increased flow as well as the major source of contaminants. Whilst Australian studies have recorded runoff events as high as $32 \%$ of inflow water (Austin et al. 1996; Bush \& Austin 2001), the irrigation losses of $40-60 \%$ regularly recorded here were considerably higher. We do need to emphasize here, however, that this is probably not typical for the catchment. However, results from the second year of monitoring (to be in a future report) show that over-watering is occurring regularly and that losses of around $25 \%$ of inlet flow are not unusual. These obviously exceed the recommended (Australian) limits of no more than $10 \%$ of inflow (Nexhip \& Austin 1998; Nexhip et al. 1997). Even when irrigation times were halved for event 7, run-off losses still remained high at $40 \%$, although this may have been lower had the SMC been less than 30\% v/v.

Calculations for water delivery indicate that gate times are set to deliver a depth of 90-100 $\mathrm{mm}$ across the border area. The soil type in the upper part of the Waikakahi catchment is predominantly Temuka silt loam, a gley soil of slow natural drainage (Hewitt 1993), consequently if the inflow rate and border gradient are too high then the irrigation water will move down and across the surface far faster than it could completely infiltrate into the soil. This is of concern both environmentally and in terms of the efficient use of irrigation water. It is possible that the border gradient may be more suited for the faster draining Eyre soils that predominate in the lower catchment.

Variance in total inflow volume between the three borders and consequently, run-off volume, was attributed to obstacles (eg. weeds, eroded banks etc.) within the headrace channel obstructing flow. This decreases the hydraulic head at the furthest away borders while causing unintended inflow at the nearer weirs. Headrace condition is known to be important in achieving even watering (Fitzgerald \& Lauder 1963) because of the increased frictional forces and turbulence within the channel if these are not regularly cleaned and maintained. However, headrace condition is but one of a number of factors affecting run-off volumes. Observations of further borders in the lower catchment in Year 2 has identified a number of other issues that reduce flood-irrigation performance and whilst some of these might seem relatively simple to cure, they are nonetheless occurring. They are:

\section{Incorrect timing}

Some borders appear inaccurately timed for the correct amount of watering required at the time. Short borders are most at risk of over-watering.

\section{Soil water monitoring}

The absence of any soil water monitoring equipment on most farms means that the paddock is often irrigated regardless of its actual soil moisture status.

\section{Border maintenance}

Borders can be worn down by stock movement, allowing flow to leak into other borders.

\section{Diagonal borders}

Borders of differing length within a set mean that they are often timed to irrigate the longest one, causing overflow in the shortest.

\section{Border design}

The toe-end of paddocks bordering drainage channels or the stream itself often drop away at the ends, allowing direct access of run-off to the stream. These require bunding (a raised outer-containing border) to contain any surplus flow. 


\section{Headrace condition}

The condition of older head races can be of concern with erosion, damage, subsidence and flow obstructions affecting the hydraulic head between borders.

\section{Malfunctions}

Clocks that fail to trip and gates that leak allow unintentional watering. The rudimentary nature of equipment means incidents of overwatering occur and more frequently than assumed.

These issues will be reported more fully at a later date.

\section{Faecal bacteria losses}

The $E$. coli MPN's in the overflow from flood irrigation were very high and similar to concentrations measured from rainfall induced runoff experiments (Doran \& Linn 1979; Edwards et al. 2000). The significance of the relationship between faecal bacteria numbers and maximum temperatures and days-since-grazing, both strongly suggest that they are important factors in runoff bacteria concentrations. The higher prevailing temperatures over summer, combined with freshly deposited dung means die-off is slowed and may in fact lead to faecal bacteria proliferating.

The run-off estimated to be entering the Waikakahi Stream can account for a large proportion of the high faecal bacteria counts measured in the stream in summer flows (Table 3). Loadings discharged from the catchment will generally be less than the total inputs due to retention within drainage channels and in-stream processes (sedimentation and die-off) that reduce bacterial numbers within the stream flow. Even allowing for the crudeness of our estimations (we have assumed $25 \%$ loss of inflow from only $20 \%$ of the catchment), without any other obvious sources of faecal indicator bacteria of this magnitude (no point source discharges or direct animal access), irrigation run-off remains the most probable source of stream faecal coliforms.

\section{Nutrient losses}

Recorded P losses were environmentally significant at $\sim 3 \mathrm{~kg} \mathrm{P} / \mathrm{ha}$, if not as high as those recorded in Australian border-dyke studies $(6-17 \mathrm{~kg} \mathrm{P} / \mathrm{ha} / \mathrm{y})$ for dairy farming (Nexhip \& Austin 1998). Actual losses, however, would have been greater than this as several irrigation events were not attended over the irrigation season and no measurements made. The fact that stream flow in summer triples in volume compared with winter (Meredith et al. 2003 ) is primarily attributed to these large volumes of run-off and contributing sub-surface flow. The contaminants contained mean that water quality is likely being compromised by these $\mathrm{P}$ and $\mathrm{N}$ losses. Irrigation soon after grazing particularly increased dissolved unreactive-P, a portion of which is available to plants and algae (McDowell et al. 2001). The sources of $\mathrm{P}$ appear to be principally from high surface soil-P concentrations (soil had Olsen P test of $45 \mu \mathrm{g} / \mathrm{ml}$ ) and deposited dung but their exposure to loss is probably increased after pasture defoliation as well as from the vegetation itself (Nexhip et al. 1997). The traffic of stock over the paddock surface and reduced vegetation cover after recent grazing means that there is greater interaction between surface soil and water and opportunity for $\mathrm{P}$ to dissolve than if there is substantial pasture present. Good pasture cover slows water advance, reducing turbulence and filtering out particles across the surface. It is also possible that more laminar-type flow conditions prevail in heavy vegetation cover allowing the water-soil surface interface to remain relatively stationary.

Of particular interest were the high $\mathrm{P}$ concentrations of the irrigation run-off after superphosphate (and urea) fertiliser had been applied 10 days previously. According to the recently updated (2002) Fertiliser Industry's Fertiliser Code of Practice (FMRA 1998), the only requirement in respect to fertiliser application is not to irrigate within 24 hours of application. This may need to be re-assessed in light of this work and border-dyke irrigation research conducted in Australia which also shows increased nutrient losses from irrigation run-off after recent fertiliser addition (Austin et al. 1996; Bush \& Austin 2001).

Nitrogen losses were lower than P losses but still remained well above critical limits (for water quality) at times and increased significantly with irrigation soon after grazing. The proportion of the daily $\mathrm{N}$ loading calculated as originating from run-off however, is a much smaller fraction $(<10 \%)$ of the total stream loading suggesting that its origin is probably from sub-surface flow into the stream. Nevertheless, the application of urea prior to the last irrigation event (event 7) did appear to elevate $\mathrm{NH}_{4}^{+}{ }^{-} \mathrm{N}$ concentrations in irrigation run-off by an order of magnitude and may also need to be reappraised in light of the fertiliser application recommendation comments above.

\section{Conclusions}

The losses of water, faecal bacteria and nutrients reported in this study from a flood-irrigated dairy paddock serve to emphasize the significant potential for waterway contamination if Best Practice management is not followed. Reducing the volume of irrigation run-off on paddocks with direct access to drainage channels entering the stream remains the single-most important step to improving water quality in the Waikakahi stream. Volumes of runoff in this study from the Waikakahi field site were large and comprised, on average, $50 \%$ of the inflow. However, these values are unlikely to be typical for the remainder of the catchment. Excess runoff 
appeared to be predominantly the result of insufficient infiltration occurring on the slower-draining Temuka soils, suggesting that the border gradient may be too steep for this soil type. At the very least, reducing irrigation duration is required to decrease inflow volume and hence, irrigation run-off. Lowering the border gradient should be considered for slower-draining soil types when recontouring the paddock surface.

The unequal inflow between borders, and unintended inflow from irrigation of the adjacent border set, appears due to flow obstacles within the headrace channel and increased turbulence. This decreases the hydraulic head at the furthest away borders and consequently, reduces flood-irrigation performance so maintaining channels correctly is important. A number of other issues affecting flood irrigation performance were identified and will be more fully reported on after further measurements in the Waikakahi catchment in 2004.

Whilst reducing the volume of irrigation run-off is the first priority to limit $\mathrm{P}$ inputs into the drainage system, reducing Olsen $\mathrm{P}$ levels for soils to the target range of 20-30 $\mu \mathrm{g} / \mathrm{ml}$, the timing of fertiliser application, and days between irrigation and last grazing, are also important determinants of nutrient concentrations in irrigation runoff.

\section{ACKNOWLEDGEMENTS}

Funding of this research as part of the Best Practice Catchments Programme is gratefully acknowledged from Fonterra and Dairy InSight with special thanks to Dave and Ron Crooks for generously allowing the use of their farm and supporting this work with their time.

\section{REFERENCES}

Austin, N. R.; Prendergast, J. B.; Collins, M. D. 1996. Phosphorus losses in irrigation runoff from fertilized pasture. Journal of Environmental Quality 25: 63-68.

Blakemore, L. C.; Searle, P. L.; Daly, B. K. 1987: Methods for Chemical Analysis of Soils. Scientific Report 70. NZ Soil Bureau, Lower Hutt. 100 pp.

Bush, B. J.; Austin, N. R. 2001. Timing of phosphorus fertilizer application within an irrigation cycle for perennial pasture. Journal of Environmental Quality 30: 939-946.

Department of Health 1992: Provisional Microbiological Water Quality Guidelines for Recreational and Shellfish-Gathering Waters in New Zealand. Public Health Services Dept of Health, Wellington. 17 pp.

Doran, J. W.; Linn, D. M. 1979. Bacteriological quality of runoff water from pastureland. Applied and Environmental Microbiology 37: 985-991.

Ebina, J.; Tsutsui, T.; Shirai, T. 1983. Simultaneous determination of total notrogen and phosphorus in water using peroxodisulphate oxidation. Water
Research 17: 1721-1726.

Edberg, S. C.; Allen, M. J.; Smith, D. B. 1988. National field evaluation of a defined substrate method for the simultaneous enumeration of total coliforms and Escherichia coli from drinking water: comparison with the standard multiple tube fermentation method. Applied and Environmental Microbiology 54: 15951601

Edwards, D. R.; Larson, B. T.; Lim, T. T. 2000. Runoff nutrient and fecal coliform content from cattle manure application to fescue plots. Journal of the American Water Resources Association 36: 711-721.

Fitzgerald, P. D.; Lauder, B. A. 1963. The effect of race condition on head losses in irrigation ditches. New Zealand Engineering 17: 16-18.

FMRA 1998: Code of Practice for Fertiliser Use. Auckland, New Zealand Fertiliser Manufacturers' Research Association. Updated 2002 ed. 21 pp.

Hewitt, A. E. 1993: New Zealand soil classification. Landcare Research Science Series No. 1. Dunedin, Manaaki Whenua Press. 2nd ed. 133 pp.

McDowell, R. W.; Sharpley, A. N.; Condron, L. M.; Haygarth, P. M.; Brookes, P. C. 2001. Processes controlling soil phosphorus release to runoff and implications for agricultural management. Nutrient Cycling in Agroecosystems 59: 269-284.

Meredith, A.; Smith, Z.; Lavender, R. 2003: Waikakahi stream: assessment of water quality and ecosystem monitoring, 1995-2002. Technical report R03/14. Environment Canterbury, Christchurch. 67 pp.

Ministry for the Environment 2003: Water Quality Guidelines - Part Two E: Microbiological Guidelines for Freshwaters. At: www.mfe.govt.nz/publications/ water/microbiological-quality-jun03/

Mundy, G. N.; Nexhip, K. J.; Austin, N. R.; Collins, M. D. 2003. The influence of cutting and grazing on phosphorus and nitrogen in irrigation runoff from perennial pasture. Australian Journal of Soil Research 41: 675-685.

Nexhip, K. J.; Mundy, G. N.; Collins, M. D.; Austin, N. R. 1997: Development of nutrient water quality targets for irrigated pasture sub-catchments. Final report Project I5037. Institute of Sustainable Irrigated Agriculture, Tatura, Victoria. $143 \mathrm{pp}$.

Nexhip, K. J.; Austin, N. R. 1998: Defining key nutrient reduction practices for irrigated dairy pastures. pp. 533-543. In: Water is Gold. Irrigation Association of Australia Proceedings.

Niemela, S. I.; Lee, J. V.; Fricker, C. R. 2003. A comparison of the International Standards Organisation reference method for the detection of coliforms and Escherichia coli in water with a defined substrate procedure. Journal of Applied Microbiology 95: 12851292. 
